\title{
Foliicolous lichens from Suriname and Guyana: new records and three new species
}

\author{
Pieter P. G. van den Boom ${ }^{1} \&$ Harrie J. M. Sipman ${ }^{2}$ \\ ${ }^{1}$ Arafura 16, NL-5691 JA Son, the Netherlands. \\ E-mail: pvdboom@kpnmail.nl \\ ${ }^{2}$ Freie Universität Berlin, Botanischer Garten und Botanisches Museum, Königin-Luise-Straße 6-8, \\ D-14195 Berlin, Germany. E-mail: h.sipman@bgbm.org
}

\begin{abstract}
Sampling of foliicolous lichens by the first author in Suriname in 2014 resulted in 103 records of lichenized and lichenicolous fungi for Suriname, including 89 first records for the country and one undescribed species. Fieldwork in Guyana by the second author in 1992 and 1997 brought 29 new records, including a new chemical strain for Loflammea epiphylla and two undescribed species. A full list for Suriname is presented (130 taxa), the additions for Guyana are listed, and the new species Calenia surinamensis, Enterographa paruimae and Strigula transversoundulata are described.
\end{abstract}

Key words: Lichenized Ascomycetes, biodiversity, rainforests, Neotropics.

\section{INTRODUCTION}

The central north-coast of South America has a humid, tropical climate and extensive tropical lowland rainforests have survived there until now. The core area consists of two smaller countries and an overseas department, Guyana (British Guiana), Suriname (Dutch Guiana) and French Guiana. They are taken together as the Guianas and their flora, including their mycota, is being studied by the Flora of the Guianas international research project, a co-operation between several countries. This project organized several expeditions to sample the biodiversity, mostly in Guyana and French Guiana. Lichenological results so far are a checklist (Hekking \& Sipman 1988) and treatments for the families Physciaceae (Aptroot 1987), Trichotheliaceae (Aptroot \& Sipman 1993) and Cladoniaceae (Ahti \& Sipman 2013).

Moreover, in the Guianas a diverse foliicolous lichen mycota appears to be present. This has been studied by, e.g., Santesson (1952), Sipman (1991, 1997), Sipman \& Aptroot (1992) and, by far the most extensively, Lücking (1998, 2006, 2008). As a result currently 298 foliicolous species are known from the three countries together: 241 from Guyana, 222 from French Guiana and 21 from Suriname (Santesson 1952, Sipman 1991, 1997, Lücking 1998, 2006, 2008).

Ongoing studies show that these figures are still far from complete, and that the group is badly understudied in Suriname. To improve the knowledge for Suriname, the first author made a two weeks field trip through the north- ern part of the country, sampling corticolous and foliicolous lichens and lichenicolous fungi. Here we present the foliicolous species of this trip, found mainly in secondary rainforest and on one occasion in a somewhat disturbed primary rainforest (Brownsberg). Added are results from unstudied collections made in the 1990s in Guyana by the second author and some further unpublished specimens kept in B.

\section{MATERIALS AND METHODS}

All specimens have been studied by conventional macro- and microscopical techniques with hand-cut sections of the material mounted in tap water. Amyloid reactions were tested using Lugol's iodine solution (K/I) and chemistry was occasionally tested by TLC (Orange et al. 2001). Voucher specimens for Suriname are kept in the herbarium of P. van den Boom, for Guyana in herbarium B. For the identification of the specimens mostly the monograph on foliicolous lichens of the Neotropics by Lücking (2008) was used.

\section{List of localities (with their identification numbers) in Suriname, visited by P. \& B. van den Boom in 2014}

4. Paramaribo, $\mathrm{N}$ of centre, along Kanangalaan, cultuurtuin, small tropical forest with some cacao trees, $15 \mathrm{~m} .5^{\circ} 50.70^{\prime} \mathrm{N}, 5^{\circ} 09.60^{\prime} \mathrm{W}$. 21.02.2014. 
9. Saramacca: W of Paramaribo, between Uitkijk and Groningen, E of Kampong Baroe, farm with path along field, orchard and swamp, $4 \mathrm{~m} .5^{\circ} 45.00^{\prime} \mathrm{N}, 55^{\circ} 23.30^{\prime} \mathrm{W}$. 23.02.2014.

10. Saramacca: W of Paramaribo, $4 \mathrm{~km} \mathrm{SE}$ of Groningen, Bloemendaal, very small village, garden with Coccoloba uvifera and other trees and shrubs, $8 \mathrm{~m} .5^{\circ} 45.75^{\prime} \mathrm{N}$, $55^{\circ} 27.78^{\prime} \mathrm{W}$. 23.02.2014.

11. Saramacca: W of Paramaribo, $4 \mathrm{~km} \mathrm{~W}$ of Groningen, along main road ( $\mathrm{N}$ site), abandoned citrus orchard and trail along swamp, 5 m. $5^{\circ} 49.40^{\prime} \mathrm{N}, 55^{\circ} 30.30^{\prime} \mathrm{W}$. 24.02.2014.

12. Saramacca: W of Paramaribo, $12 \mathrm{~km} \mathrm{~W}$ of bridge near Boskamp (from river 'Coppename'), near ponds, trail in tropical forest, $7 \mathrm{~m} .5^{\circ} 46.57^{\prime} \mathrm{N}, 56^{\circ} 00.32^{\prime} \mathrm{W} .25 .02 .2014$.

14. Saramacca: W of Paramaribo, $5 \mathrm{~km} \mathrm{E}$ of Groningen, Vanckweg, unpaved road among gardens and fields, $20 \mathrm{~m} .5^{\circ} 47.85^{\prime} \mathrm{N}$, 55 ${ }^{\circ}$ 29.02'W. 26.02.2014.

16. Para: S of Paramaribo, Domburg, area of Surinat, La Rencontre 5e street, orchards, roadside trees and small patches of secundary tropical forest, $12 \mathrm{~m} .5^{\circ} 41.31^{\prime} \mathrm{N}$, 55 ${ }^{\circ} 04.24^{\prime} \mathrm{W}$. 27.02.2014.

18. Para: S of Paramaribo, S of Lelydorp, SE of Bernharddorp, botanical garden, dominated by Heliconia, with palm trees and various broadleaf trees, $10 \mathrm{~m} .5^{\circ} 36.12^{\prime} \mathrm{N}$, $55^{\circ} 11.25^{\prime} \mathrm{W}$. 1.03.2014.

19. Wanica: S of Paramaribo, Leylydorp, Neotropical Butterfly Park, 8 m. 5 41.27'N, 55¹2.09’W. 1.03.2014.

20. Commewijne: SSE of Paramaribo, Laarwijk (plantage), houses with orchards of mainly citrus and banana, and small secondary tropical forest, $5 \mathrm{~m} .5^{\circ} 42.30^{\prime} \mathrm{N}, 5^{\circ} 03.70^{\prime} \mathrm{W}$. 2.03.2014.

21. Wanica: SSE of Paramaribo, NNW of Domburg, road along Surinameriver, to Paramaribo, Boxel, roadside trees and trees at edge of small forest, $8 \mathrm{~m} .5^{\circ} 42.40^{\prime} \mathrm{N}, 55^{\circ} 05.90^{\prime} \mathrm{W}$. 3.03.2014.

24. Brokopondo: S of Paramaribo, Brownsberg Natuurpark, primary tropical forest, c. $4 \mathrm{~km}$ $\mathrm{S}$ of Brownsweg, unpaved road to the mountain top, trail in forest, $100 \mathrm{~m} .4^{\circ} 59.50^{\prime} \mathrm{N}$, $55^{\circ} 11.54^{\prime} \mathrm{W}$. 5.03.2014.

25. Brokopondo: S of Paramaribo, S of Brownsweg, Brownsberg Natuurpark, primary tropical forest, top of the mountain, trail in forest, 'natuurpad' and trail to waterfall, 500 m. $4^{\circ} 57.00^{\prime} \mathrm{N}, 55^{\circ} 10.94^{\prime} \mathrm{W}$. 5.03.2014.

\section{List of localities (with their identification numbers) in Guyana, visted by H. Sipman in 1992 and 1997}

92-6. Upper Takutu district, southern Rupununi savannah. Track from Dadanawa ranch to Aishalton, at border of the ranch. Elev. c. 120 m. c. $2^{\circ} 40^{\prime} \mathrm{N}, 59^{\circ} 24^{\prime} \mathrm{W}$. Low forest along creek (Wariwau?) in savannah. Foliicolous in undergrowth. 22.09.1992.

92-13. Upper Takutu district, southern Rupununi savannah. Kusad mountain, SE-side. Elev. c. 450 m. $2^{\circ} 47^{\prime} \mathrm{N}, 59^{\circ} 51^{\prime} \mathrm{W}$. Forest along stream in upper part of valley. Foliicolous in undergrowth. 29.09.1992.

92-14. Upper Takutu district, southern Rupununi savanna. Kusad mountain, SE-side. Elev. c. 600 m. c. $2^{\circ} 47^{\prime} \mathrm{N}, 59^{\circ} 50^{\prime}$ W. c. 15 $\mathrm{m}$ tall, undisturbed forest on rocky ridge; foliicolous. 30.09.1992.

92-18. Upper Takutu district, c. $40 \mathrm{~km} \mathrm{~S}$ of Aishalton. Kuyuwini Landing. Elev. c. 230 m. c. $2^{\circ} 06^{\prime} \mathrm{N}, 59^{\circ} 15^{\prime} \mathrm{W}$. Foliicolous in undergrowth of c. $30 \mathrm{~m}$ tall, seasonally dry, undisturbed forest on N-shore of Kuyuwini river. 8-15.10.1992.

92-19. Upper Takutu district, c. $40 \mathrm{~km} \mathrm{~S}$ of Aishalton. c. $2 \mathrm{~km}$ S of Kuyuwini Landing, along trail to Kassikaityu river. Elev. c. 230 m. c. $2^{\circ} 06^{\prime} \mathrm{N}, 59^{\circ} 15^{\prime} \mathrm{W}$. c. $30 \mathrm{~m}$ tall, seasonally dry, undisturbed forest. 9-13.10.1992.

92-20. Upper Takutu district, c. $50 \mathrm{~km} \mathrm{~S}$ of Aishalton. c. $6 \mathrm{~km}$ S of Kuyuwini Landing, along trail to Kassikaityu river. Elev. c. 280 m. c. $2^{\circ} 01^{\prime} \mathrm{N}, 59^{\circ} 15^{\prime} \mathrm{W}$. Foliicolous in undergrowth of c. $25 \mathrm{~m}$ tall, seasonally dry, undisturbed forest. 18-23.10.1992.

92-29. East Demerara district. Mabura Hill, near scientific field station c. $13 \mathrm{~km} \mathrm{~S}$ of the village. Elev. c. $100 \mathrm{~m} .5^{\circ} 18^{\prime} \mathrm{N}, 58^{\circ} 42^{\prime} \mathrm{W}$. Undisturbed, c. $25 \mathrm{~m}$ tall forest on laterite on slope and in stream valley. Foliicolous in undergrowth. 14.11.1992.

97-18. Region 7 (Upper Mazaruni Distr.): Paruima Mission, along Kamarang river 2-3 $\mathrm{km} \mathrm{S}$ of the village. Elev. c. $500 \mathrm{~m} .5^{\circ} 47^{\prime} \mathrm{N}$, $61^{\circ} 04^{\prime} \mathrm{W}$. In forest at foot of plateau. Foliicolous in undergrowth. 9.05.1997. 


\section{RESULTS}

In the new samples from Suriname104 species of foliicolous lichens were found. Of these 95 are new records for the country. One is an apparently unknown taxon, described below as Calenia surinamensis. Together with three species found in unpublished samples in B, and six species reported before (Santesson 1952, Lücking 2008), altogether 114 species are known now from Suriname. A full list is presented below.

For the much better investigated Guyana, 31 species were newly recorded, including two apparently unknown taxa which are described below as Enterographa paruimae and Strigula transversoundulata. One sample constitutes a new chemotype of Loflammia epiphylla.

The new records are mostly species known already from elsewhere in the Guianas. However, 24 taxa have not been found in all three Guianas before, and indicate that the foliicolous lichen diversity of this area is still far from completely known.

\section{List of the foliicolous lichens and licheni- colous fungi known from Suriname}

For each species the locality identification numbers (see Material and Methods) are given in brackets, followed by the collection number of the first author, where applicable. An asterisk (*) before the species name indicates new records for Suriname; two asterisks $(* *)$ indicate new records for the three Guianas. For species without new records literature references are given.

\section{A. Lichenized fungi:}

*Actinoplaca strigulacea Müll. Arg. - (10) 50548; (24) 51083.

*Anisomeridium folitcola R. Sant. \& Tibell - (24) 51075.

*ARTHONIA ACINIFORMis Stirt. - (25) 51190.

*ARthonia cyanea Müll. Arg. f. minor - (10) 50540.

*ARTHONia LeCYTHidicola (Bat. \& H. Maia) Lücking \& Sérus. - (25) 51112.

**Aspidothelium GEMiniparum (Malme) R. Sant. (11) 50616, 50588.

*Aspidothelium SCUTELLICARPUM Lücking - (9) 50497, 51187.

AsterothyriUm MONOSPORUM Müll. Arg. - Lücking 2008: 406.

ASTERothyrium PITTIERI Müll. Arg. - (19) 50923.

*ASTEROTHYRIUM TETRASPORUM Lücking - (9) 50489.

**Asterothyrium UNiSEPTATUM Lücking - (16) 50765.
*Aulaxina minuta R. Sant. - (20) 50930a, 50936; (24) 51050; (25) 51095.

*AulaXina Quadrangula (Stirt.) R. Sant. - (10) 50539.

*Bacidina APiahica (Müll. Arg.) Vězda - Saramacca: Coppename River, near the base of the Voltzberg. c. $4^{\circ} 45^{\prime} \mathrm{N}, 56^{\circ} 15^{\prime} \mathrm{W}$. Foliicolous in undergrowth of primary forest. 28 Jan. 1999. P. Hiepko 3533 [B].

*Bacidina hypophylla Lücking \& Kalb - (24) 51047, 51079; Saramacca: Coppename River, near the base of the Voltzberg. c. $4^{\circ} 45^{\prime} \mathrm{N}, 56^{\circ} 15^{\prime} \mathrm{W}$. Foliicolous in undergrowth of primary forest. 28 Jan. 1999. P. Hiepko 3529 [B].

*BACIDINA NEOTROPICA Lücking - (25) 51132.

Badimia dimidiata (C. Bab. ex Leight.) Vězda (24) 51057; Nickerie: area of Kabalebo Dam project. Line near $\mathrm{Km} 34$. Highland forest. Foliicolous on $30 \mathrm{~cm}$ tall shrublet. 30 Oct. 1981. R. Zielman 1363b [B, BBS].

*Bapalmuia Palmularis (Müll. Arg.) Sérus. - (25) 51098; Saramacca: Coppename River, near the base of the Voltzberg. c. $4^{\circ} 45^{\prime} \mathrm{N}, 56^{\circ} 15^{\prime} \mathrm{W}$. Foliicolous in undergrowth of primary forest. 28 Jan. 1999. P. Hiepko 3536 [B].

*BRasilicia BRAsiliensis (Müll. Arg.) Lücking \& Kalb - (24) 51053; (25) 51099.

*Byssoloma aurantiacum Kalb \& Vězda - (25) 51089.

*Byssoloma citricola (Maubl.) Lücking, Sérus. \& R. Sant. - (13) 50677, 50678.

*Byssoloma leucoblepharum (Nyl.) Vain. - (10) 50537; (16) 50712; (21) 50983, 50996.

*Byssoloma minutissimum Kalb \&Vězda - (16) 50725, 50736; (20) 50959.

*Byssoloma subdiscordans (Nyl.) P. James - (10) 50530.

*Byssoloma tricholomum (Mont.) Zahlbr. - (12) 50645.

*Calenia depressa Müll. Arg. - (20) 50937.

CALENIA DictYospora Lücking - Lücking 2008: 510.

\section{**Calenia surinamensis van den Boom \& Sipman sp. nov. (Fig. 1)}

\section{Mycobank no.: MB 817432}

Diagnosis: Similar to Calenia chroodisciformis Lücking, but thallus pale greenish grey to greenish, apothecia up to $0.5 \mathrm{~mm}$ diam., ascospores 2-4 per ascus, 26-33 × 11-16 $\mu \mathrm{m}$, muriform with 4-7 transverse septa and 2-4 segments 

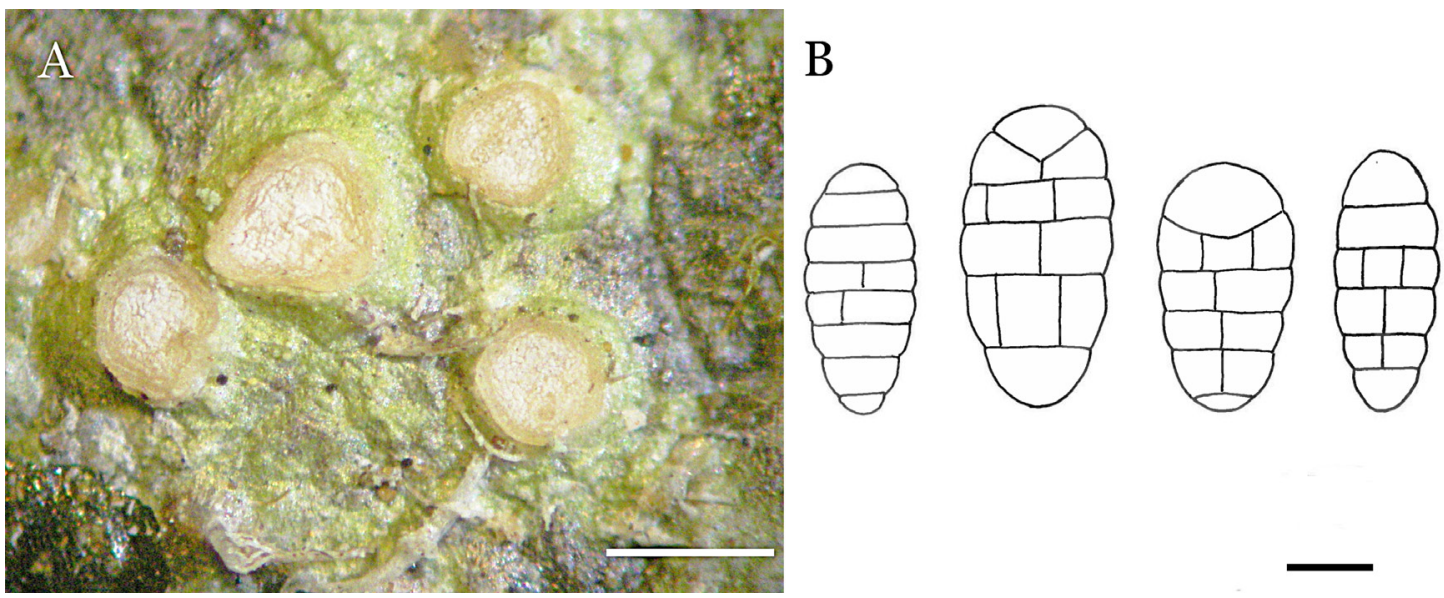

Fig. 1. A-B: Calenia surinamensis, type specimen. A. Habitus, thallus and apothecia; B: ascospores. Scale: $\mathrm{A}=500 \mu \mathrm{m} ; \mathrm{B}=10 \mu \mathrm{m}$.

with 1-2 longitudinal septa, slightly constricted at the septa.

Type: SURINAME, Wanica: S of Paramaribo, Lelydorp, Neotropical Butterfly Park, with mixed trees and shrubs, $8 \mathrm{~m} .5^{\circ} 41.27^{\prime} \mathrm{N}, 55^{\circ} 12.09^{\prime} \mathrm{W}$. 1 March 2014. P. \& B. van den Boom 50925 (B-holotype; hb v.d. Boom isotype).

Description: Thallus continuous or dispersed, 5-25 mm across, 5-10 $\mu \mathrm{m}$ thick, with cartilaginous corticiform layer, with calcium oxalate crystals, also beneath the apothecia, pale greenish grey to greenish, slightly shiny. Photobiont chlorococcoid (Trebouxia). Apothecia erumpent to sessile, rounded to angular, $0.2-0.5 \mathrm{~mm}$ diam. and up to $0.15 \mathrm{~mm}$ high; margin very distinct, strongly prominent, entirely pale greyish cream, excipulum prosoplectenchymatous, 5-10 $\mu \mathrm{m}$ broad, hyaline, laterally covered by a small corticiform layer; disc greyish to pale cream, covered by white pruina; hypothecium 5-15 $\mu \mathrm{m}$ high, colorless; epithecium pale yellow to brownish, with a layer of colorless granules; hymenium 50-75 $\mu \mathrm{m}$ high, colorless, I-, KI-; paraphyses thin, richly branched and anastomosing; asci 2-4-spored, cylindrical to slightly clavate, $50-55 \times 14-20 \mu \mathrm{m}$; ascospores broadly ellipsoid, 26-33 × 11-16 $\mu \mathrm{m}$, muriform, with 4-7 transverse septa and 2-4 segments with 1-2 longitudinal septa, slightly constricted at the septa. Hyphophores not observed.

Chemistry: not tested (there are no substances known from this genus).
Etymology, distribution and ecology: The new species is named after the country where it has been found, a Neotropical species only known from the type collection, found in a small disturbed forest in a more or less urbanized area. Accompanying species are: Asterothyrium pittieri, Calopadia puigarii and Echinoplaca cf. leucotrichoides.

Notes: Lücking (2008) described seven new species of Calenia from the Neotropics, two from Brazil and five from Costa Rica. Three of these are very similar to the new species. Calenia surinamensis resembles most of all Calenia chroodisciformis Lücking in habitus, a species from Costa Rica but that species has a more greyish thallus, smaller apothecia (0.15-0.25 $\mu \mathrm{m}$ diam.), 4-8 ascospores per ascus and ascospores of 15-22 × 6-8 $\mu \mathrm{m}$. Calenia pseudographidea Lücking, also known from Costa Rica (Lücking 2008), has apothecia of $0.4-0.7 \mathrm{~mm}$ diam. with an irregular, lobulate margin and a flesh-colored disc; the ascospores are of rather the same size as the new species, but are 5-9-septate, with one longitudinal septum in 1-2 segments. Further, the new species is easily confused with Calenia obtecta Lücking, also known from Costa Rica, which has apothecia of $0.2-0.4 \mathrm{~mm}$ diam. with plane, pale yellow, translucent, white-pruinose apothecia, but the ascospores are single, clearly muriform and 35-55 × 15-25 $\mu \mathrm{m}$.

*Calenia triseptata Zahlbr. - (20) 50965.

*Caleniopsis conspersa (Stirt.) Lücking et al. (25) 51101, 51142. 
*Calopadia foliicola (Fée) Vězda - (16) 50766.

*CAlopadia fusca (Müll.Arg.) Vězda - (20) 50935.

**Calopadia perpallida (Nyl.) Vězda - (14) 50688.

*Calopadia phyllogena (Müll. Arg.) Vězda - (11) 50617; (20) 50964; (21) 50985.

*Calopadia puiggari (Müll. Arg.) Vězda - (16) 50705; (19) 50926.

*Calopadia subcoerulescens (Zahlbr.) Vězda (10) 50538.

*Chroodiscus australiensis Vězda \& Lumbsch - (25) 51106.

*CHROOdiscus coccineus (Leight.) Müll. Arg. - (12) 50625; (18) 50918; (24) 51049; (25) 51126.

*Chroodiscus NeOtropicus Kalb \& Vězda - (24) 51048.

**Coenogonium barbatum Lücking, Aptroot $\&$ Umaña - (25) 51087, 51119.

*Coenogonium ciliatum Kalb \& Lücking - (24) 51062; (25) 51137.

**Coenogonium Dilucidum (Kremp.) Kalb \& Lücking - (16) 50549, 50770.

*Coenogonium hypophyllum (Vězda) Kalb \& Lücking - (25) 51139; Saramacca: Coppename River, near the base of the Voltzberg. c. $4^{\circ} 45^{\prime} \mathrm{N}, 56^{\circ} 15^{\prime} \mathrm{W}$. Foliicolous in undergrowth of primary forest. 28 Jan. 1999. P. Hiepko $3532[\mathrm{~B}]$.

**Coenogonium Lisowski (Vězda) Lücking - (16) 50741; (20) 50931.

**CoENoGoniUm SIQUiRRENSE (Lücking) Lücking (12) 50641; (16) 50690; (25) 51090.

*Coenogonium subluteum (Rehm) Kalb \& Lücking - (4) 50373, 50378; (11) 50589; (16) 50706, 50745; (20) 50934, 50939, 50940, 50948; (21) 50980.

*Echinoplaca epiphylla Fée - (11) 50614; (20) 50966.

**ECHINOPLACA HANDELII (Zahlbr.) Lücking - (10) 50631.

*EChinoplaca leucotrichoides (Vain.) R. Sant. (11) 50590(cf.), B50591; (12) 50626, 50630; (19) B50929(cf.).

*Fellhanera bouteillei (Desm.) Vězda - (4) 50380.

FellhaneRa Flavostanhopeae Lücking $\&$ R. Sant. - Lücking 2008: 655.

FellhaneRa fuscatula (Müll. Arg.) Vězda - (16) 50707, 50744; (21) 50982; (25) 51086, 51125.

*Fellhanera RHaPhidophylli (Rehm) Vězda - (21) 50998; (24) 51081; Saramacca: Coppename River, near the base of the Voltzberg. c. $4^{\circ} 45^{\prime} \mathrm{N}, 56^{\circ} 15^{\circ} \mathrm{W}$. Foliicolous in undergrowth of primary forest. 28 Jan. 1999. P. Hiepko 3530 [B].

*Fellhanera stanhopeae (Müll. Arg.) Lücking, Lumbsch \& Elix - Saramacca: Coppename River, near the base of the Voltzberg. c. $4^{\circ} 45^{\prime} \mathrm{N}, 56^{\circ} 15^{\prime} \mathrm{W}$. Foliicolous in undergrowth of primary forest. 28 Jan. 1999. P. Hiepko 3524 [B].

*Fellhanera SubFuscatula Lücking - (24) 51077.

*FELLHANERA VERRUCIFERA Lücking var. nigrescens Lücking - (24) 51045, 51055.

*Flavobathelium ePiPhyllum Lücking, Aptroot \& Thor - (24) 51071, 51082.

*Gyalectidium filicinum Müll. Arg. - (9) 50494, 50496; (16) 50737; (24) 51056; (25) 51096.

**GYALIDEOPSIS LOBULATA Lücking - (20) 50967.

*Lasioloma ARACHNOIDEUm (Kremp.) R. Sant. - (9) 50506; (16) 50764; (24) 51060 (cf.).

LYROMMA ORNATUM Lücking, Kalb \& Sérus. - Lücking 2008: 187.

Mazosia Dispersa (Hedr.) R. Sant. - Lücking 2008: 156.

*Mazosia melanopthalma (Müll. Arg.) R. Sant. (25) 51145.

*Mazosia Phyllosema (Nyl.) Zahlbr. - (10) 50534; (11) 50620; (18) 50919, 50920; (24) 51052, 51063.

MaZosia PRAEMorsa (Stirt.) R. Sant. - (25) 51118.

*Mazosia Rotula (Mont.) A. Massal. - Saramacca: Coppename River, near the base of the Voltzberg. c. $4^{\circ} 45^{\prime} \mathrm{N}, 56^{\circ} 15^{\prime} \mathrm{W}$. Foliicolous in undergrowth of primary forest. 28 Jan. 1999. P. Hiepko 3525 [B].

*Opegrapha filicina Mont. - (25) 51121.

*Phyllobathelium anomalum Lücking - Emmaketen mountains, $800 \mathrm{~m} \mathrm{~N}$ of South Camp. Xeromorphic forest on rock; on small tree, Myrt. 1176. 28 Sept. 1959. A. G. H. Daniëls \& F. P. Jonker 1176a [B].

*Phyllobathelium firmum (Stirt.) Vězda - (24) 51043; In montibus Bakhuis inter flum. Kabalebo et Coppename Sinistrum. $9 \mathrm{~km}$ downstream of base-camp. River bank. 3 Feb. 1969. P. A. Florschütz \& P. J. M. Maas 2762k [B].

*Phyllobathelium leguminosae (Cavalc. \& A. A. Silva) Lücking \& Sérus. - Brokopondo: Nat. Res. Brownsberg, on plateau, from path to Witiecreek. Alt. ca. 500 m. c. $5^{\circ} \mathrm{N}, 55^{\circ} \mathrm{W}$. Foliicolous on Anona. 24 Oct. 1981. R. Zielman $1344 \mathrm{~g}$ [B].

*Phyllobathelium thaXteri (Vain.) Zahlbr. - (20) 50968; Saramacca: Coppename River, near 
the base of the Voltzberg. c. $4^{\circ} 45^{\prime} \mathrm{N}, 56^{\circ} 15^{\prime} \mathrm{W}$. Foliicolous in undergrowth of primary forest. 28 Jan. 1999. P. Hiepko 3531 [B].

*Porina AlBA (R. Sant.) Lücking - (21) 50986; Saramacca: Coppename River, near the base of the Voltzberg. c. $4^{\circ} 45^{\prime} \mathrm{N}, 56^{\circ} 15^{\prime} \mathrm{W}$. Foliicolous in undergrowth of primary forest. 28 Jan. 1999. P. Hiepko 3534 [B].

*Porina atrocoerulea Müll. Arg. - (9) 50502.

*Porina distans Vězda \& Vivant - (16) 50750.

*Porina epiphylla (Fée) Fée - (12) 50629, 50644; (16) 50718, 50720, 50721; (24) 51070; (25) 51085, 51116, 51135.

*Porina fUlvella Müll. Arg. - (25) 51131.

*PoRINA FUSCA Lücking - (16) 50711; (24) 51054; (25) 51144.

*Porina leptosperma Müll. Arg. - (24) 51084.

*Porina luCida R. Sant. - (18) 50917; (25) 51120.

*Porina nitidula Müll. Arg. - (4) 50365, 50374; (9) 50508; (16) 50740.

*Porina OCTOMERA (Müll. Arg.) F. Schill. - (16) 50749.

Porina RADIATA Kalb, Lücking \& Vězda - (25) 51088.

*Porina RUBEnTIOR (Stirt.) Müll. Arg. - (16) 50722; (18) 50921; (24) 51072; (25) 51107, 51109, 51128.

*Porina subePiPhylla Lücking \& Vězda - (12) 50634.

*Porina tetramera (Malme) R. Sant. - (10) 50533, 50547; (16) 50704, 50710, 50717, 50727; (20) 50952, 50961.

SPOROPODIUM ANTONIANUM Elix, Lumbsch \& Lücking - Lücking 2008: 774.

*Sporopodium citrinum (Zahlbr.) Elix - (16) 50767.

*SPoropodium Leprierii Mont. - (24) 51046, 51065; Saramacca: Coppename River, near the base of the Voltzberg. c. $4^{\circ} 45^{\prime} \mathrm{N}, 56^{\circ} 15^{\prime} \mathrm{W}$. Foliicolous in undergrowth of primary forest. 28 Jan. 1999. P. Hiepko 3528 [B].

Strigula Antillarum (Fée) Müll. Arg. - (9) 50509.

*Strigula concreta (Fée) R. Sant. - (9) 50500, 50503; (12) 50621; (16) 50726, 50739, 50769; (20) 50956.

*Strigula Maculata (Cooke \& Massee) R. Sant. (20) 50946; (25) 51122.

*STRIGULA MicRospora Lücking - (25) 51094.

Strigula nemathora Mont. - (4) 50366; (12) 50642; (16) 50731; (20) 50955; Saramacca: Coppename River, near the base of the Voltzberg. c. $4^{\circ} 45^{\prime} \mathrm{N}, 56^{\circ} 15^{\prime} \mathrm{W}$. Foliicolous in undergrowth of primary forest. 28 Jan. 1999. P. Hiepko 3535 [B].

Strigula Nitidula Mont. - (20) 50950, 50963; (21) 50995.

*Strigula obducta (Müll. Arg.) R. C. Harris - (24) 51074; (25) 51108.

*STRIGUla ORBICULARIS Fr. - (9) 50505.

Strigula phyllogena (Müll. Arg.) R. C. Harris (24) 51044, 51066; (25) 51140.

Strigula PlatyPoda (Müll. Arg.) R. C. Harris (25) 51110.

*Strigula schizospora R. Sant. - (16) 50713; (20) 50938.

STRIGULA SMARAGDULA Fr. - (4) 50377, 50492; (14) 50693; (25) 51127.

*Strigula subelegans Vain. - (16) 50732.

*Strigula subtilissima (Fée) Müll. Arg. - (16) 50715, 50739a; (18) 50922; (25) 51105.

*TAPELLARIA MAJOR (Lücking) Lücking - (12) 50638.

*TAPELLARIOPSIS OCTOMERA Lücking - (10) 50537a.

*Tricharia urceolata (Mull. Arg.) R. Sant. - (11) 50615, 50619; (16) 50728, 50748; (20) 50957, B50962; (24) 51076; (25) 51115, 51134.

*TRICHARIA VAINIOI R. Sant. - (20) 50953; (21) 50997; (24) 51076a.

TRICHOTHELIUM BIPINDENSE F. Schill. - (16) 50714; (24) 51073.

*Trichothelium JURUense (P. Henn.) F. Schill. (25) 51117.

*TRICHOTHELIUM MINUS Vain. - (9) 50495; (16) 50622, 50708; (20) 50930, 50947, 50949, 50954; (25) 51143.

*TRICHOTHELIUM MINUTUM (Lücking) Lücking - (16) 50532.

*Trichothelium Pallescens (Müll. Arg.) F. Schill. - (20) 50932(cf.), 50958.

TRICHOTHELIUM PALLIDISETUM Lücking - Lücking 2008: 350.

\section{B. Lichenicolous fungi:}

**Keratosphaera dimerellae Matzer - (4) 50379, on Coenogonium subluteum.

*Opegrapha PHYlloporinae Müll. Arg. - (18) 50916 (cf.); (24) 51188, on Porina sp.

\section{List of new records from Guyana}

For each species locality identification numbers (see Material and Methods) are given in brackets, followed by the collection number and the herbarium barcode of the specimen in square 
brackets. An asterisk (*) before the species name indicates new records; two asterisks $\left(^{* *}\right)$ indicate new records for the Guianas.

\section{A. Foliicolous lichens:}

*Aspidothelium PAPILLICARPUM Lücking - (92-18) 36916 [В 60 0200497]; (92-29) 61619 [B 60 0200257]; (97-18) 61488 [B 600194743$].$

**BACIDINA DEFECTA Vězda - (92-20) 37080 [B 60 0200509].

**BACIDINA SIMPLEX var. CYANOPHILA Lücking - (9229) 61624 [B 60 0200261].

*Byssolecania hymenocarpa (Vain.) Kalb et al. (92-29) 61630 [B 60 0200267].

*Byssoloma humboldtianum Lücking \& Kalb - (9220) 37106 [B 60 0200529]. Det. R. Lücking.

*BYSSOLOMA HYPOPHYLlum Lücking \& Kalb - (9229) 61637 [B 600200271$]$.

*CRyptothecia effusa (Müll. Arg.) R. Sant. - (9219) 37040 [B 60 0200565], in canopy of $15 \mathrm{~m}$ tall understory tree Licania sprucei (Chrysobal.), at 10-15 $\mathrm{m}$ height.

\section{**Enterographa paruimae Sipman sp. nov.}

(Fig. 2)

\section{Mycobank no.: MB 817433}

Diagnosis: A foliicolous species of Enterographa most similar to E. meklitiae, sharing the clustered ascocarps with 4 spores per ascus and the exciple filled with crystals, but differing by the 5-6-septate instead of 4-5-septate ascospores and the partly open ascocarps with brown discs.

Type: GUYANA, Region 7 (Upper Mazaruni Distr.): Paruima Mission, along Kamarang river 2-3 km S of the village. Alt. c. $500 \mathrm{~m} .5^{\circ} 47^{\prime} \mathrm{N}$, $61^{\circ} 04^{\prime} \mathrm{W}$. In forest at foot of plateau. Foliicolous in undergrowth. 9 May 1997. H. Sipman 61521 [B 60 0194766-HOLOTYPE].

Description: Thallus continuous, ca. $1 \mathrm{~cm}$ in diam., smooth but without evident cortex, thin (ca. $10 \mu \mathrm{m}$ ), greenish grey; photobiont probably Phycopeltis, forming irregularly arranged, somewhat branched and winding threads with almost cylindrical, greenish cells ca. $10 \times 5 \mu \mathrm{m}$, hardly constricted at the septa. Ascomata sessile, clustered with ca. $2-10$ in ca. $0.2-0.6 \mathrm{~mm}$ wide and $0.2 \mathrm{~mm}$ tall groups, with greenish grey to whitish (when damaged), smooth margins and closed or open, to $0.1 \mathrm{~mm}$ wide, brown discs. Excipulum pale, except for a brown rim around the hymenium, indistinctly delimited from the thallus, filled with coarse colorless crystals of ca 5-10 $\mu \mathrm{m}$ in diam.; hypothecium colorless, thin; hymenium $50 \mu \mathrm{m}$ high, I+ pale blue turning reddish, top pale brown, stronger I+ blue. Asci ca. $28 \times 9 \mu \mathrm{m}$, Opegrapha-type; ascospores fusiform, 18-20 × $4 \mu \mathrm{m}, 5-6$-septate, thin-walled, 4/ ascus. Pycnidia not seen. Chemistry: no lichen substances (TLC, Pd-negative).

Etymology, distribution and ecology: Named after the type locality and known only from the type specimen, found on leaves in undergrowth of tropical lowland forest.

Notes: The new species keys out near E. perezhigaredae Herrera-Camp. \& Lücking on account of its foliicolous habitat preference (Lücking 2008, Savey \& Savey 2014). This species shares the small, rounded, brown ascocarps but differs by the larger ascospores, $26-30 \times 3-4 \mu \mathrm{m}$ instead of $18-20 \times 4 \mu \mathrm{m}$, and its ascocarps are not
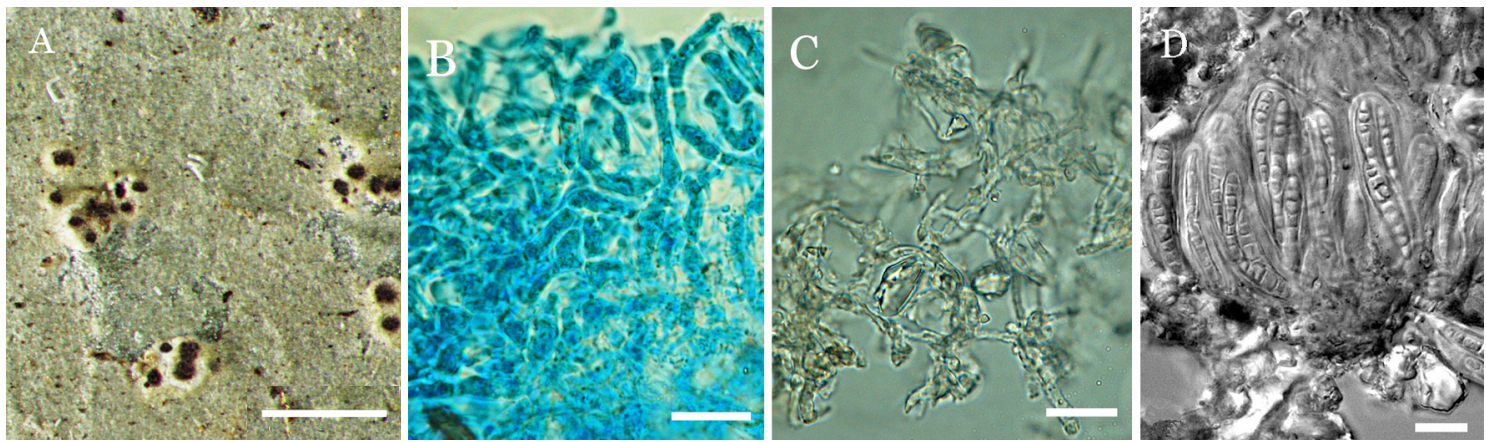

Fig. 2. A-D: Enterographa paruimae, type specimen. A. Ascoma aggregates; B. photobiont, stained by Lactophenol-cottonblue; C. squash of exciple showing crystals; D. asci with 7-loculate spores. Scale: $\mathrm{A}=500 \mu \mathrm{m} ; \mathrm{B}, \mathrm{C}, \mathrm{D}=10 \mu \mathrm{m}$. 
clustered. Several further species with rounded ascocarps have become known recently, but none foliicolous (Aptroot et al. 2013). However, two foliicolous species with clustered, rounded ascocarps were described recently from Africa (Ertz 2009, Yeshitela et al. 2009). Of these, E. meklitiae Yeshitela, Eb. Fisch., Killmann \& Sérus. seems the most similar to E. paruimae, the most obvious difference being in the slightly more numerous spore septa, 5-6 instead of 4-5 and the higher number of ascocarps per cluster, 8-12(-20) instead of ca. 2-10. Moreover no open discs seem to occur in the African species, and it is stated to be lichenicolous on a foliicolous Coenogonium species with Trentepohlia sp. with angular-rounded cells as photobiont. In our material the ascocarps seem to develop on their own thallus, with cf. Phycopeltis in loose threads as photobiont. This thallus does not resemble the thalli of crustose Coenogonium species.

*Eschatogonia dissecta Timdal \& R. Sant. (92-20) in $37127=$ Eschatogonia sp. [B 60 0200590].

**FELlHanera PUnctata Lücking - (92-18) 36918 [B 60 0200595].

*Fellhanera RUBida (Müll. Arg.) Lücking - (92-18) 36912 [B 60 0200596].

*Graphis furcata Fée - (92-19) 37048 [B 60 0200602], in canopy of $15 \mathrm{~m}$ tall understory tree Licania sprucei (Chrysobal.), at 10-15 $m$ heigth.

*Loflammia EPIPHYlla (Fée) Lücking \& Vězda - (9718) 61532 [B 60 0192607]; (92-29) in 61705 = Phylloblastia amazonica [B 60 0200313]. The treatment of a microscopic preparation with $\mathrm{KOH}$ solution resulted in clusters of red needle-shaped crystals, characteristic for norstictic acid; this substance and zeorin were confirmed by TLC. This deviates from Lücking (2008: 776) who reports atranorin, stictic and hypostictic acids and indicates the presence of a different chemotype, containing zeorin and norstictic acid. In view of the usually tiny thalli of foliicolous lichens no effort has been made to test further specimens of this species by TLC, so that the distribution of the new chemotype remains unclear.

**LYROMMA CONFUSUm Lücking \& Sérus. - (97-18) 61533 [B 600192641 ].

**LyRomma dolicobelum Cavalc. - (92-20) 37109 [B 60 0200616]; (92-20) in $37081=$ Brasilicia brasiliensis [B 60 0200520].
*Malmidea gyalectoides (Vain.) Kalb \& Lücking - (92-20) 37153 [B 60 0200618].

**Mazosia conica Sérus. - (92-29) 61668 [B 60 0200290].

**Mazosia UnisePtata Lücking - (92-20) 37122a [B 60 0200621]. The identification is tentative because the ascocarps are less distinctly volcano-shaped (Lücking 2006) and the hymenium is lower, $25-35 \mu \mathrm{m}$ instead of $50-70$ $\mu \mathrm{m}$. The ascocarps of $M$. adelphoparasitica Matzer seem more similar (Matzer 1996, Fig. 29), but have equally a higher hymenium of $50-70 \mu \mathrm{m}$, and no host ascocarps for this lichenicolous species are visible in our specimen (Fig. 3).

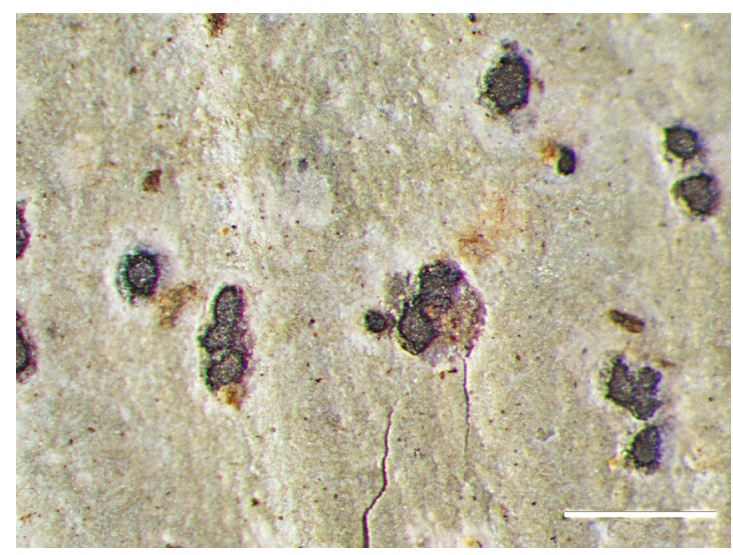

Fig. 3. Mazosia cf. uniseptata, ascocarps. Scale: $500 \mu \mathrm{m}$.

\footnotetext{
**PoRINA MORALESIAE Lücking - (97-18) 61565 [B 60 0194733].

**Porina RUBEscens (Lücking) Hafellner \& Kalb - (97-18) 61571 [B 60 0192630].

*Porina tetracerae (Ach.) Müll. Arg. - (92-18) 36967 [В 60 0200410]; (92-20) 37131 [B 60 0200411]; (92-20) 37136 [B 600200412$]$; (92-29) 61735 [В 60 0200331]; (97-18) 61575 [В 60 0192638].
}

\section{**Strigula transversoundulata Sipman sp. nov. (Fig. 4)}

Mycobank no.: MB 817434

Diagnosis: Similar to Strigula subtilissima by the thin thallus divided into linear, black-rimmed lobes and conical perithecia, but with thicker, transversely wrinkled, often radiating thallus lobes. 

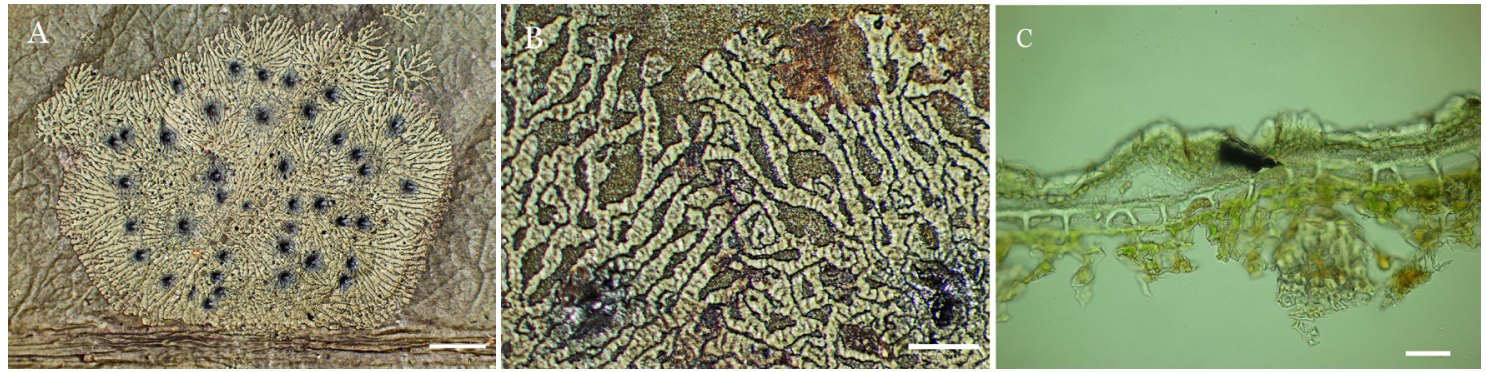

Fig. 4. A-C: Strigula transversoundulata, type specimen. A. Thallus with radiating lobes, perithecia and micropycnidia; B. Detail of thallus lobes with transversely wrinkled surface and perithecia; C. Thallus section, showing (from above to below) the cuticula, the thallus of the lichen with black lobe rim, and rectangular periderm cells of the host. Scale: A, B $=500 \mu \mathrm{m}$; C $=20 \mu \mathrm{m}$.

Type: GUYANA, East Demerara district. Mabura Hill, near scientific field station c. $13 \mathrm{~km}$ S of the village. Alt. c. $100 \mathrm{~m} .5^{\circ} 18^{\prime} \mathrm{N}, 58^{\circ} 42^{\prime} \mathrm{W}$. Undisturbed, c. $25 \mathrm{~m}$ tall forest on laterite on slope and in stream valley. Foliicolous in undergrowth. 14 Nov. 1992. H. Sipman 61761 [B 60 0200346-HOLOTYPE].

Description: Thallus subcuticular, yellowgreenish, glossy, thin and hardly raised above the leaf surface, forming roundish patches of ca. 6-10 $\mathrm{mm}$ in diameter, which may become confluent and cover large parts of leaves; completely divided into linear, $0.1-0.2 \mathrm{~mm}$ wide, dichotomously branching lobes with slightly sinuose, black-rimmed margins; the lobes contiguous and radiating or separate and irregularly spreading, with transversely undulate surface, to ca. $25 \mu \mathrm{m}$ thick in the wrinkles, about $10 \mu \mathrm{m}$ in between; algal cells ca. $6-10 \times 5 \mu \mathrm{m}$, rounded, in indistinct chains constricted at the septa, multilayered. Perithecia $0.4-0.5 \mathrm{~mm}$ in diam., ca. $200 \mu \mathrm{m}$ high, conical with rounded tip and spreading base, black and glossy near the tip, lower down covered by thalline lobes; wall black and carbonized thoughout; asci subcylindrical, 50-60 × 4-5 $\mu \mathrm{m}$; ascospores 8/ascus, uniseptate, not splitting, biseriate, 10-14 $\times 2-3 \mu \mathrm{m}$. Micropycnidia present, ca. $100 \mu \mathrm{m}$ wide, lenticular, black and glossy; conidia non-septate, narrowly fusiform, ca. $5 \times 1.2 \mu \mathrm{m}$.

Chemistry: not tested (there are no substances known from this genus).

Etymology, distribution and ecology: The name of the new species refers to the transverse ridges on the thallus lobes. It is so far known only from two localities in northern and southern Guyana, from living leaves in undergrowth of primary tropical rainforest.

Notes: The new species is very similar to $S$. subtilissima, with which it shares the linear, black-rimmed thallus lobes and the characters of perithecia and micropycnidia. However, the two specimens included in this new taxon differ clearly from the numerous specimens of $S$. subtilissima available in herbarium B by the transverse wrinkles of the thallus lobes when dry, where the thallus may become up to $25 \mu \mathrm{m}$ thick; in S. subtilissima sensu stricto the lobes are flat and 8-12 $\mu \mathrm{m}$ thick (Lücking 2008: 242). The lobes are generally wider, often about 0.2 $\mathrm{mm}$ wide over longer stratches, against mostly up to $0.1 \mathrm{~mm}$ in $S$. subtilissima. The pronounced radiating arrangement of the lobes, which is common in $S$. transversoundulata, is absent in S. subtilissima. It should be taken into account that hypocuticular Strigula species may show much variation in thallus development, depending on characters of the host leaves. The most pronounced example is probably $S$. nemathora Mont. (see Santesson 1952). However, the numerous differences of $S$. transversoundulata from its closest relative, $S$. subtilissima, and a detailed study of many collections of this species convinced us that a separate species is at hand. Moreover the two available samples are evidently from different host species, which reduces the probability that the differentiating characters are depending on the host.

Additional specimen examined: (92-20) 37145 [B 60 0200424]. 
*STRIGULA NIGROCARPA Lücking - (92-14) 61750 [B 60 0194828]; (92-20) 37270 [B 60 0200440], in canopy of $11 \mathrm{~m}$ tall understory tree Licania densiflora (Chrysobal.) at 9-12 $\mathrm{m}$ heigth.

*TAPELlaria Nigrata (Müll. Arg.) R. Sant. - (92-13) 61763 [B 600194819$]$; (92-14) 61754 [B 60 0194837]; (92-6) 61762 [B 600200347$].$

*TAPELLARIOPSIS OCTOMERA Lücking - 1992 (92-18) 36980 [B 60 0200454]; (92-19) 37051 [B 60 0200455], in canopy of $15 \mathrm{~m}$ tall understory tree Licania sprucei (Chrysobal.), at 10-15 m heigth; (92-6) 61765 [B 60 0200348]. Specimens 36980 and 37051 were identified by Lücking in 1995, and have campylidia but lack apothecia.

*TRICHARIA LONGISPORA Kalb \& Vězda - (92-20) 37267 [B 60 0200457], in canopy of 11 $\mathrm{m}$ tall understory tree Licania densiflora (Chrysobal.) at 9-12 m heigth; (97-18) 61593 [B 600194716$]$.

*TRICHOTHELIUM PALLIDisetum Lücking - (97-18) 61590 [B 60 0192618].

\section{B. Lichenicolous fungi:}

**EPIBRyon LICHENICOLA Matzer - (92-20) 37157 [B 60 0200588], on Mazosia melanophthalma (Müll. Arg.) R. Sant. and on M. tumidula (Stirt.) Zahlbr.

**HEMigRaPHA STRIGULAe Matzer - (92-20) 37272

[B 60 0200606], on Strigula nemathora Mont.

\section{ACKNOWLEDGEMENT}

Thanks are due to Dr. R. Lücking (Berlin) for the identification of Byssoloma humboldtianum and Tapellariopsis octomera. Special thanks are for the first author's wife, Bern van den Boom, who by her keen eyes contributed many interesting discoveries during the field work. The head of the Suriname Forest Service (Paramaribo) is gratefully acknowledged for providing the export permit.

\section{REFERENCES}

Ahti, T. \& Sipman, H. J. M. 2013. Cladoniaceae. In: Flora of the Guianas, Series E: Fungi and Lichens, Fascicle 3. Royal Botanic Gardens, Kew, Richmond, UK. 132 pp.

Aptroot, A. 1987. Pyxinaceae (Lichens). In: Flora of the Guianas, Series E: Fungi and Lichens, Fascicle 1. Koeltz Scientific Books, Koenigstein, Germany. 59 pp.
Aptroot, A., Ertz, D., De Lima, E. L., De Jesus, K. A., Maia, L. C. \& Cáceres, M. E. D. S. 2013. Two new species of Roccellaceae (Ascomycota: Arthoniales) from Brazil, with the description of the new genus Sergipea. Lichenologist 45(5): 627-634. http:// dx.doi.org/10.1017/S0024282913000303

Aptroot, A. \& Sipman, H. J. M. 1993. Trichotheliaceae (Lichens). In: Flora of the Guianas. Series E: Fungi and Lichens, Fascicle 2. Koeltz Scientific Books, Koenigstein, Germany. 57 pp.

Ertz, D. 2009. A new species of Enterographa, E. diederichiana (Roccellaceae), from Zambia. Bryologist 112(2): 390-393. http://dx.doi. org/10.1639/0007-2745-112.2.390

Hekking, W. H. A. \& Sipman, H. J. M. 1988. The lichens reported from the Guianas before 1987. Willdenowia 17: 193-228.

Lücking, R. 1998. Foliicolous lichens and their lichenicolous fungi collected during the Smithsonian International Cryptogamic Expedition to Guyana 1996. Tropical Bryology 15: 45-76. http:/ / dx.doi. org/10.11646/bde.15.1.7

Lücking, R. 2006. Foliicolous lichens from French Guiana (northeastern South America). Cryptogamie, Mycologie 27(2): 121-147.

Lücking, R. 2008. Foliicolous Lichenized Fungi. Flora Neotropica Monograph 103. Organization for Flora Neotropica and The New York Botanical Garden Press, Bronx, New York. 866 pp.

Matzer, M. 1996. Lichenicolous Ascomycetes with Fissitunicate Asci on Foliicolous Lichens. Mycological Papers 171. CAB International, Wallingford. 202 pp.

Orange, A., James, P. W. \& White, F. J. 2001. Microchemical Methods for the Identification of Lichens. British Lichen Society. 101 pp.

Santesson, R. 1952. Foliicolous lichens I. A revision of the taxonomy of the obligately foliicolous, lichenized fungi. Symbolae Bot. Upsal. 12(1): 1-590.

Seavey, F. \& Seavey, J. 2014. New additions to the lichen genus Enterographa (Roccellaceae) from Everglades National Park including an updated world key. Lichenologist 46(1): 83-93. http:// dx.doi.org/10.1017/S0024282913000662

Sipman, H. J. M. 1991. Notes on the lichen flora of the Guianas, a neotropical lowland area. In: Galloway, D. J. (ed.): Tropical Lichens: Their Systematics, Conservation, and Ecology. Systematics Association Special Volume, Clarendon Press, Oxford, pp. $135-150$.

Sipman, H. J. M. 1997. Observations on the foliicolous lichen and bryophyte flora in the canopy of a semi-deciduous tropical forest. Abstracta Botanica 21(1): 153-161.

Sipman, H. J. M. \& Aptroot, A. 1992. Results of a botanical expedition to Mount Roraima, Guyana. II. Lichens. Tropical Bryology 5: 79-108.

Yeshitela, K., Fischer, E., Killmann, D. \& Sérusiaux, E. 2009. Two new foliicolous species of Enterographa (Roccellaceae) from Kenya. Lichenologist 41(1): 17-23. http://dx.doi.org/10.1017/ S0024282909008299 